atom, is that the routo of formation of 70 per cent of the total carbon dioxide and 90 per cent of the carbon dioxide derived from C-1 of glucose is unknown. It is suggested that the net output of carbon dioxide from the tricarboxylic acid cycle is less than 3 per cent of the observed production, so that some alternative mechanism must exist for the degradation of glucose to carbor dioxide. Recent findings in other laboratories indicate that a transketolasetransaldolase cycle might be involved.

Thus the report ends with new questions being posed-which is just as it should be. This is an essentially personal account, with five authors whose different styles are apparent but not disconcertingly so. Some readers will challenge the conclusion that the micro-organisms used are freely permeable to ions and small molecules, including hexose phosphates and glutathione, and others will question whether the time is ripe for application, as it were, of Kirchhoff's laws to living organisms. Thero is little discussion of related findings by other workers using other techniques, but (perhaps as compensation) there is a classified bibliography of well over a thousand post-1940 papers on the biochemistry of Escherichia coli and other topics relevant to the text. Two useful appendixes on the kinetics of incorporation and dilution are also included. There is a wealth of illustration, including some thirty full-page reproductions of radioautographs. The text, which is reproduced by a lithographic process, is easy to read and the figures are well drawn, but some, in the chapter on sulphur metabolism, have inadequate legends. The few misprints are mainly confined to tables.

The Carnegie Institution of Washington was founded "to encourage, in the broadest and most liberal manner, investigation, research, and discovery ...". It is well served by a director such as Dr. Merle A. Tuve, who enthusiastically supports a group of his physicists when they break away into microbiology and when they justify themselves, as in this first major progress report, by writing of "the intense personal pleasure that has come to us in this research".

KENNETH MCQUILLEN

\section{THE HAUNTING OF BORLEY RECTORY}

The Haunting of Borley Rectory

By Eric J. Dingwall, Kathleen M. Goldney and Trevor H. Hall. Pp. xiv $+181+5$ plates. (London: Gerald Duckworth and Co., Ltd., 1956. Published under the auspices of the Society of Psychical Research.) 16s. net.

THIS account of the evidence for abnormal happenings in what the late Harry Price described as "the most haunted house in England" well maintains the tradition of the Society for Psychical Research for honest and cautious study of alleged parapsychological phenomena. A heavy task was undertaken at the invitation of the Society by three trained investigators. Their story is at times as interesting as a detective novel; it reveals queer actions of some vory curious people; it leaves very little to be explained of the actual haunt itself and a good deal to be puzzled over in the motives, actions and reactions of the people principally concerned. The general conclusion is that credulity, mal- observation, trickery and fraud account for the great bulk of the recorded evidence.

Criticism has been directed against the Society for Psychical Research for having so long delayed an inquiry into Borley Rectory. The relevant facts are these. The case first achieved more than local notoriety in June 1929, when the incumbent, the Rev. Eric Smith, wrote to the editor of the Duily Mirror asking for advico as to whom to consult as to the best method of clearing the rectory of its bad local reputation as a haunted house. The results were visits from a reporter and from Harry Price. Articles published in the paper brought crowds of sightseers to the rectory; the situation developed rapidly and was soon out of control. Serious investi. gation became impracticable, and in any event Harry Price had taken over the case. Two visits were actually paid by Lord Charles Hope, later a member of the Society's council, in July 1929; he came away with the view that the phenomena were produced by normal means and with the suspicion that Harry Price was responsible for some of them. Public interest was maintained, however, by Harry Price sending a rota of (untrained) investigators to report on the haunting and by his two books on Borley Rectory. The Society took up the challenge of this continued publicity in 1949 after Mrs. Eric Smith had written to the Daily Mail to express her disbelief in the haunting of the rectory. Price had died in 1948 but his literary executor, Paul Tabori, gave facilities to the investigators to examine his files and correspondence in the Harry Price library. A large part of the case against Harry Price comes from his own writings and papers. Doubts about the genuineness of the phenomena produced in the presence of Mrs. Foyster, wife of a later incumbent of Borley, were also expressed by Price and are strongly underlined in this report.

The destruction of the rectory by fire in 1939 has not ended the story of the haunt, nor the popular interest in Borley. The writers of this book give good reasons why the vague stories of its early haunting and also the more recent accounts need not be taken seriously, and why their report can fairly be taken as "The End of Borley Rectory". The tragedy is that it brings discredit to the name of one who had done so much to bring psychical research to the notice of the general public.

\section{F. J. M. Strkatton}

\section{GENETIC RECOMBINATION}

\section{Symposium on Genetic Recombination}

Given at the Research Conference for Biology and Medicine of the Atomic Energy Commission, Oak Ridge, Tennessee, April 19-21, 1954. (Reprinted from .Journal of Cellular and Comparative Physio. logy, Vol. 45, Supplement 2, May 1955.) Pp. vii + 321. (Philadelphia, Pa. : Wistar Institute of Anatomy and Biology, 1955.) n.p.

$\mathrm{N}$ the late 'twenties and early 'thirties there was 1 great interest among geneticists and cytologists in attempts to understand the mechanism by which genetic crossing-over takes place. It was believed by many that this would prove a profitable way to attack the problem of gene and chromosome structure. Although several useful working hypotheses were formulated, these hopes were not realized. In fact, 